\title{
Ve-Shuv Limlakhah u-Shvut: An Older Theoretical Framework
}

\author{
Marcus Mordecai Schwartz
}

Rabbinic tradition has generally divided Shabbat prohibitions into two major categories: melakhah and shevut. ${ }^{1}$ Unfortunately the protean vibrancy of these two terms, particularly the latter, has allowed them to escape clear definition. ${ }^{2}$ The purpose of this paper is to present a working definition of shevut that reflects the enormous amount of change and dynamism that have characterized these two terms over the course of their existence. To be clear: My presentation in this paper is far from exhaustive, nor does it represent my final considered opinion on the matter. This paper is more of a first attempt to come to terms with the significance that the continually shifting nature of these two classifications of Shabbat practice holds for our contemporary context. Down the road, in later more developed work, I hope to foster an understanding of these practices that is faithful to precedent while recognizing the need to develop a 21st-century practice of Shabbat that is both relevant and practical. The extraordinary cultural disruption that modernity and its aftermath have imposed upon the people Israel obliges us to recover and restore the practice of Shabbat in an age when most Jews no longer observe it.

1 Joel Roth divides these prohibitions into three categories in Joel Roth, "Melakhah U'Shevut: A Theoretical Framework," Conservative Judaism 35, no. 3 (Spring 1982): 4-34. However, the first two of his categories are subdivisions of the melakhah prohibition.

2 In addition to Roth, a number of contemporary scholars have made attempts to define these terms. Though overly credulous of rabbinic legal myth making, Boaz Cohen nicely collects the major sources in Boaz Cohen, "Sabbath Prohibitions Known as Shebut," Proceedings of the Rabbinical Assembly 9 (1949): 123-161. I would not really call his discussion a historical analysis per se, but it is a coherent conceptualization based upon an exhaustive collection of the historical sources. Three other excellent discussions of both the origin and definitions of these terms are: (1) Y.D. Gilat, "On the 39 Shabbat Avot-melakhot" [in Hebrew], Tarbiz 29 (1959): 222-228; (2) Aviad Stollman, Babylonian Talmud, Eruvin X: Critical Edition with Comprehensive Commentary [in Hebrew], vol. 7 of Talmud Haiggud (Jerusalem: Society for the Interpretation of the Talmud, 2006), 164-165; 275 n. 4; 286, n. 8; 357-358; (3) Richard Hidary, "One May Come to Repair Musical Instruments': Rabbinic Authority and the History of the Shevut Laws," JSIJ 13 (2015): 1-26. Both Gilat and Hidary appear awake to the shifting nature of the two prohibitions. 
In working up a definition of the two terms, I find it quite difficult to assign either word a single meaning immediately and without hesitation. As we will see over the course of our discussion, the two terms are complementary rather than oppositional. They are a coupled pair and have undergone change as a coupled pair. The definition of each one rests to a significant degree on the meaning vested in its companion. When we attempt to define the one, we return to the other only to find that it has shifted while we were observing the first. This polysemous syzygy renders all definitions dependent and provisional. Perhaps, for the moment, the best working definition I am able to propose may be that shevut (literally "cessation" or "resting") represents the positive side of the commandment to rest on Shabbat, while melakhah (literally "craft" or "task") represents the negative side. In other words, melakhah is the sort of work one refrains from on Shabbat, while shevut encompasses the act of resting. See the appendix at the end of this paper to see the biblical background of these terms.

Of course the difficulty here is that the manner in which one positively ceases or rests from an act is to stop doing it. As such, shevut demands that we avoid behaviors which interfere with the act of resting on Shabbat. Thus, rather than seeing shevut as a positive commandment, we are captured by the illusion that it is merely another (perhaps lesser) sort of Shabbat prohibition. Indeed, we shall see that the positive encouragement to refrain from particular acts that is embodied in shevut is conceptualized by the Bavli as a series of rabbinic prohibitions.

I am not the first to define these fields of practice in this complex, yet seemingly binary manner; namely that melakhah directly forms the negative prohibitions of its kind, while shevut is derived from a positive impulse-yet indirectly creates all manner of prohibitions of its own sort. In this paper I will present two conceptions of shevut that hold fast to this composite scheme, though in different ways: That of Maimonides and that of Nahmanides. We shall see both of them attempting to explain shevut as the positive commandment to rest on Shabbat, while simultaneously maintaining the more recent Amoraic understanding of shevut as a rabbinic prohibition. This puts both of them under an interpretive strain. The distorting effect of this strain results in two deeply creative conceptual reworkings of the category.

Maimonides' definition of shevut is undoubtedly one of the oddest descriptions of any legal concept in the Mishneh Torah:

The Torah states (Exod 23:12), "you shall rest." You must cease even behaviors that are not melakhah. And the things that the Sages forbade for the 
sake of rest (shevut) are numerous. Some of them are prohibited because they are akin to melakhah, and some of them are prohibited as a circumscription to prevent encroachment on prohibitions punishable by stoning. ${ }^{3}$

Three things in this statement would have had the effect of defamiliarizing shevut to Maimonides' audience. ${ }^{4}$ First, his audience would clearly have been conditioned to view shevut as nothing more than a rabbinic prohibition. Isaac Alfasi puts forth this view in his treatment of b. Beșah $36 b .{ }^{5}$ Given the currency and authority of the Hilkhot Rav Alfas in place and time, one can deduce a widespread view that shevut was seen as nothing more than a rabbinic prohibition. However Maimonides grounds the practice of shevut in the Torah's positive commandment to rest. In and of itself, this can be taken as representative of one of Maimonides' typical modes of operation. He often ground rabbinic rules in Scripture. ${ }^{6}$ However his attempt to follow this typical pattern results in a near contradiction of the Bavli's claim that shevut is not a Torahlevel (de-oraita) law. B. Beșah 36 b is the most explicit on this point. Nonetheless, many passages in the Bavli tally with this understanding. These include-but are not limited to-b. Šabb. 8b, 97a, 114b, 15oa; b. 'Erub. 3ob, 32b, 34b, 98a, 103a, 105a; b. Beșah 33b. Instead he is quite explicit that shevut has its starting point in Scripture: "The Torah states (Exod 23:12), 'you shall rest (tishbot).'”

This brings us to the second point of oddness: Maimonides puts forth a hybrid system in which shevut has its inception in the Torah, but its expression in the circumscriptions enacted by the Sages. No passage in the Mishnah, nor

3 Mishneh Torah, Hilkhot Shabbat 21:1 (translation by the author).

4 The term "defamiliarization" was first coined in 1917 by Viktor Shklovsky in his essay "Art as Device". See Viktor Shklovskij (sic.), "Art as Technique," in Literary Theory: An Anthology, ed. Julie Rivkin and Michael Ryan (Malden: Blackwell Publishing, 1998). It is the method of presenting audiences with common things in unfamiliar or strange ways in order to recover and restore fresh experience of the familiar. This is exactly what Maimonides does here. For a treatment of the affinity between Shklovsky's "ostranenie" and Jacques Derrida's "différance," see Lawrence Crawford, "Viktor Shklovskij: Différance in Defamiliarization," Comparative Literature 36 (1984): 209-219.

5 Hilkhot Rav Alfas, vol. 1, ed. Nisan Zakash (Jerusalem: Mosad Ha-Rav Kook, 1969), 258. Alfasi presents the Bavli's claims that shevut is a rabbinic decree and then presents the Yerushalmi's sugya that clapping is only prohibited on Shabbat when it arises from anger. However he fails to present the Yerushalmi's discussion that precedes this sugya in the same halakhah. That sugya roots shevut in the positive commandment to rest.

6 This is a commonplace. See, for instance, Menachem Elon, Jewish Law: History, Sources, Principles [in Hebrew], vol. 2, pt. 3 (Jerusalem: Magness Press, 1988), 980-997. 
in either Talmud, nor the Tosefta, nor in any extant halakhic midrash of which I am aware advances such a theory of shevut. This is a new, foundational redrafting of the theory underpinning shevut. However, Maimonides does not make this new idea of whole cloth. It is a harmonization prompted by the multiple, differing rabbinic paradigms regarding the nature of shevut that he inherited. We shall also see that Nahmanides was prompted from the same motivations to attempt something similar.

Third, Maimonides makes it clear that there is a deep and abiding connection between melakhah and shevut. However he maintains a somewhat ambiguous stance, not clarifying the exact relationship between the two fields of observance. I suggest that this is intentional. It is clear that the two concepts are intimately linked, but that link was expressed in a variety of different ways prior to Maimonides. Vidal de Tolosa (1283-1360), one of Maimonides' closest readers and the author of the Maggid Mishnah, is unusually circumspect about Maimonides' meaning. Indeed he appears somewhat confused, and imposes the system of Nahmanides (as well as that of the Mekhilta of Rabbi Shimon b. Yohai) on our passage of the Mishneh Torah, overlaying it with two possible, contradictory meanings:

Our master's intention is [to say] that the Torah prohibited the explicitly forbidden tasks (melakhot) in detail, in accordance with the general method in which they have been explicated along with their measures. However a person could still toil at things that are not melakhot all day long. Therefore the Torah said, "rest." This is also as Nahmanides has written in his commentary to the Torah. So the Sages advanced and forbade many things. Or, perhaps our master's intent is that the rabbinic requirements to rest (shevutin) have support from the Torah: "You shall rest." This is the theory of the passages in the Mekhilta. ${ }^{7}$

De Tolosa's confusion, along with the multiple explanations he puts forth, points to the idiosyncrasy of this passage in the Mishneh Torah. The strangeness of the Mishneh Torah in this passage is suggestive of the multiple paradigms and the shifting ground upon which both melakhah and shevut rest.

Nahmanides' approach to the problem is clarifying, and makes the dynamics of the categories come to life before our eyes. He writes:

7 Ad loc. I hope to address the different complex and confusing conceptions of shevut that we find in the collections of Tannaitic midrash at another time. 
It appears to me that the meaning of the midrash [interpreting the phrase shabbaton] is that we are commanded on Yom Tov to rest from those activities that technically do not qualify as melakhah. We should not be disturbed all day to measure our grain, to weigh our fruit and possessions, to fill our vessels with wine, to move our wares, and even building stones, from house to house and place to place, and if located in a walled city, load up our donkeys, and even wine, grapes, figs, and all packages could indeed be delivered on a festival; and the marketplace would be filled with ongoing commerce, and the shops would be open and money changers' tables strewn with coins, and the workers would arise for their duties and establish their daily wages, like the rest of the week, and so on. These and similar activities, whether on Yom Tov or even Shabbat itself, all these activities do not technically constitute melakhah. Therefore, the Torah commands us "shabbaton" - that these should be days of rest and cessation of work, and not days of labor and toil. And this is a good and beautiful interpretation. ${ }^{8}$

Nahmanides puts forth the theory that work and rest are-by definitionperformative categories: The form that each category takes in practice defines the nature and character of human toil or leisure, rather than any prior fixed nature or character that toil or leisure may have possessed determining the form of their practice. What exhausts us, or refreshes us is largely a function of whether we conceive of it as work or as rest. One could engage in hard physical activity for a long time, and feel refreshed by it, if one thinks of it as rest, and yet be exhausted by several hours of doing little more than talking, if one conceives of it as work. This is to some degree subjective and temperamental, but he seems to argue that it is the shared communal perception of acts of work or rest that imbue them with their toilsome or leisure character.

In his imagined religious context, the result of the performative quality of work and rest is such that the ambience of Shabbat is the result of human action and behavior, and only in that action and behavior is Shabbat recognizable and distinct from other days of the week. As the halakhic conception of work and rest (i.e., melakhah and shevut) change, inevitably, the quality of that ambience may change. By being conscious of the changes in conception of these acts this midrashic interpretation of shabbaton arms us with sensitivity to perceive which acts are less than melakhah but still violate the aesthetics of the day.

8 Nahmanides, Commentary on the Torah, Lev 23:24. 
I hope this also arms us with the foresight to anticipate what those changing conceptions mean for the future of Shabbat in an age in which digital technology is constantly remaking our understanding of the nature of work and rest. I further pray that we will use that foresight to ensure the restoration of Shabbat to its rightful role as the guardian of the people Israel's survival and flourishing.

\section{Appendix: Melakhah and Shevut in Scripture}

The verb שבת ( $\sqrt{\hat{s} b t)}$ appears in the Torah in four passages (Gen 2:1-3; Exod 16:11-36; 23:9-12; 34:21). One is in Genesis, the other three are in Exodus. The three Exodus passages depict a commandment to rest using this verb. The noun מלאכה (melakhah) appears in six passages in which Shabbat is addressed (Gen 2:1-3; Exod 20:8-11; 31:12-17; 35:1-3; Lev 23:3; Deut 5:12-15). They appear together only once: Genesis 2:1-3. This passage is not prescriptive, being a creation narrative. There are five passages in which Shabbat is addressed, yet neither the verb שבת ( שלאכה (melakhah) appears (Lev 19:3, 30; 26:2; Num 15:32-36; 28:9-10). In order to understand what is at play here, and whether or not there are different conceptions of Shabbat commandments and prohibitions contained in the two words as they are presented in Scripture, we must first untangle the relationship between these various verses. There is also the matter of the multiple voices in which the Torah is written. I refer here to the strands of tradition or documents that certain critical Bible scholars have posited since the 19th century. ${ }^{9}$ Can the multiplicity of voices that we find in the Torah help us in determining the conception of these two terms and the extent to which the conception of Shabbat they represent differed historically in the time of the composition of the Bible? Finally, can we attribute the geographical, temporal, or ideological differences regarding the nature of Shabbat from these passages in the Torah?

For the sake of heuristic clarity I have created a chart that depicts the relationship between these various verses. I have also assigned a voice to each passage using the letters that Bible scholars have been using for some time (more than a hundred years) to refer to the documents-or strands of tradition that many claim the Torah contains. The Torah undoubtedly contains separate voices running the whole of its length that are consistent in vocabu-

9 For a good recent review of the hypothesis see Joel Baden, The Composition of the Pentateuch: Renewing the Documentary Hypothesis (New Haven: Yale University Press, 2012), 13-33. 
lary; voices that leave off in one passage and then resume at a later point in a coherent, connecting way. The consistency of style, vocabulary, theology, and more that one finds in these voices is deeply convincing that they represent consistent, sustained, coherent, and differing statements submerged below the Torah's redactional layer. I think it is clear that this is the way the Torah talksin a multiplicity of voices. ${ }^{10}$ To that extent, considering these voices and how they present the various commandments of the Torah may give us an insight into different conceptions that may have been extant at the time of the Torah's composition. In any case, in addition to assigning voices to the passages, the chart below lays out the occurrence of the two terms, or their absence, in every passage related to Shabbat in the Torah.

\begin{tabular}{|c|c|c|c|c|}
\hline עמום & שבוהת & מלאככה & קול & פרשה \\
\hline & $x$ & $x$ & $\mathrm{P}$ & בראשית ב, א-ג \\
\hline & $x$ & & $\mathrm{P} / \mathrm{J}$ & *שמות טז, יא-לו \\
\hline & & $x$ & $\mathrm{P}$ & שמות כ, ח-יא \\
\hline & $x$ & & $\mathrm{E}$ & שמות כג, ט-יב \\
\hline & & $x$ & $\mathrm{P}$ & שמות לא, יב-יז \\
\hline & $x$ & & $\mathrm{~J}$ & שמות לד, כא \\
\hline & & $x$ & $\mathrm{P}$ & שמות לה, א-ג \\
\hline$x$ & & & $\mathrm{P} / \mathrm{H}$ & ויקרא יט,ג \\
\hline \multirow[t]{2}{*}{$x$} & & & $\mathrm{P} / \mathrm{H}$ & ויקרא יט, ל \\
\hline & & $x$ & $\mathrm{P}$ & ויקרא כג, ג \\
\hline$x$ & & & $\mathrm{P} / \mathrm{H} ?$ & *ויקרא כו, ב \\
\hline$x$ & & & $\mathrm{P}$ & במדבר טו, לב-לו \\
\hline \multirow[t]{2}{*}{$x$} & & & $\mathrm{R}$ & *במדבר כח, ט-י \\
\hline & & $x$ & $\mathrm{D}_{1}$ & דברים ה, יב-טו \\
\hline
\end{tabular}

10 I think it is unduly difficult to attempt to establish an exact date for each of these voices, nor is it my duty to do so here. I will not be entering into a discussion of which of these voices preceded the other, or whether they all derive from a simultaneous moment of revelation. That is beyond the scope of this paper. 


\section{Bibliography}

Baden, Joel. The Composition of the Pentateuch: Renewing the Documentary Hypothesis. New Haven: Yale University Press, 2012.

Cohen, Boaz. "Sabbath Prohibitions Known as Shebut." Proceedings of the Rabbinical Assembly 9 (1949): 123-161.

Crawford, Lawrence. "Viktor Shklovskij: Différance in Defamiliarization." Comparative Literature 36 (1984): 209-219.

Elon, Menachem. Jewish Law: History, Sources, Principles [in Hebrew]. Vol. 2, pt. 3. Jerusalem: Magnes, 1988.

Gilat, Y.D. "On the 39 Shabbat Avot-melakhot” [in Hebrew]. Tarbiz 29 (1959): 222-228.

Hidary, Richard. “One May Come to Repair Musical Instruments': Rabbinic Authority and the History of the Shevut Laws." JSIJ 13 (2015): 1-26.

Roth, Joel. "Melakhah U'Shevut": A Theoretical Framework." Conservative Judaism 35, no. 3 (Spring 1982): 4-34.

Shklovskij [Shklovsky], Viktor. "Art as Technique." In Literary Theory: An Anthology. Edited by Julie Rivkin and Michael Ryan, 15-21. Malden: Blackwell Publishing, 1998.

Stollman, Aviad. Babylonian Talmud, Eruvin x: Critical Edition with Comprehensive Commentary [in Hebrew]. Vol. 7 of Talmud Haiggud. Jerusalem: Society for the Interpretation of the Talmud, 2006.

Zakash, Nisan, ed. Hilkhot Rav Alfas. Jerusalem: Mosad Ha-Rav Kook, 1969. 